\title{
Students' Perception towards Master of Business Studies (MBS) Semester System: A Case Study of Nepal Commerce Campus
}

\author{
Rewan Kumar Dahal \\ Lecturer, Nepal Commerce Campus
}

\begin{abstract}
The study sought to understand and analyze students' perception towards MBS semester system taking a case of Nepal Commerce Campus with regard to (a) academic resources, (b) course organization and planning, (c) physical resources, (d) governance and image, and (e) overall perception of students. It followed descriptive research design with using questionnaire survey instrument. The population of this study comprised all $668 \mathrm{MBS}$ semester students and the sample consisted 246 students selected through random sampling techniques. The survey questionnaire was set in seven sections with 30 questions of various types to collect data. Collected data were analyzed with the help of SPSS software (version 23). The research result revealed that the perception of the students towards all aspects is quite satisfactory except toilets and canteen facilities of Nepal Commerce Campus. The study drew some feedback and suggestions from students for the betterment of the college. It covered those students who were studying MBS semester system since the last five out of 48 month's course cycle therefore it didn't cover the aspects of semester system. It enhances the understanding of stakeholders about the issues of semester system at master's level.
\end{abstract}

Keywords: Perception, semester system, resources, evaluation and feedback.

\section{Introduction}

Educational system all over the world has never been consistent over the year. Through advancement and exposure to new concepts, educationists investigate possibilities to teach texts in various feasible manners (Mazumdar, 2010). According to Tribus (1994), there are innumerable proposals/suggestions for reforms and changes in educational system and there are infinite number of good ideas and research results. Introduction of semester system can be said to be the product of these investigations. Etymologically the word 'semester' originates from a Latin word 'sementris' which means 'course of six months'. The word 'Se' means Six and 'mentris' means month. So, it literally means 'half of a year' or 'one of the two divisions of an academic year'. However, a semester does not only mean dividing an academic year into two half yearly sessions. It is an innovative approach to teaching-learning process, a new educational culture, which allows greater interaction between teachers and the students (Das, 2015). According to the Dictionary of Education (1981) semester means 'half of the academic years usually 16 to 18 weeks'. 
The development of any country depends very much on the quality of education and its process and system. Education is the foundational norm for society as a whole; it is the vehicle that drives or leads the society towards betterment and fulfilment. Universities play a vital role in the development and evolution of societies. They generate new ideas, encourage innovation, educate young minds and contribute to develop dynamic citizens in the country. As a result of the impact of globalization, liberalization and privatization educational system all over the world has been changing drastically for the last few years. Because of the advancement in science and technology and exposure to new concepts and knowledge educationists all over the world have been investigating to find out more innovative and effective system of education. Semester system of education is a product of these investigations (Das, 2015). We find that most of the nations in the world today are following the semester system of education in their higher education. Materializing the scheme of semester system effectively in an environment of poor physical and information resources like Nepal is a challenging task.

The effective and successful implementation of semester system depends upon a number of conditions as stated by Jadoon, Jabeen and Zeba (2012): well-designed curriculum; course coverage within stipulated time; regularity of classes; timely and constructive feedback to students by the teachers; accessibility of teachers to students outside the class; availability of information resources to students such as stat-ofthe-art library and computer facilities; highest level of secrecy and confidentiality in examination; transparency in evaluation and grade; timely declaration of semester results etc. Aslam et al. (2012) in their study revealed that semester system is perceived to be most effective way of effectual learning. They revealed that many factors can efficiently enhance student's satisfaction but teachers' efforts and behavior are the main factors which are directly related to the students' satisfaction. According to Brophy (2014) semester has emerged as a response to the demand for individualization in education. The study suggested that the philosophy and objectives of individualization in education may indeed be achieved through the utilization of semester patterns of organization.

Nepal's education system is comparatively less exposed to international market because of two major reasons. First, development of modern education system in Nepal is recent phenomenon, particularly in the second half of twentieth century only. Second, there are serious concerns on the quality of educational systems in Nepal. In the last half century, Nepal witnessed remarkable quantitative growth in educational institutions but the quality of education could not go hand in hand with the quantitative growth. Nepal's education system also critically suffers from lack of innovation and more dependent to imitation, particularly with Indian system of education (Pokharel, n.d).

Universities should aim not only to educate young minds and contribute to make dynamic citizens, but also to generate new ideas and encourage innovation. Tribhuvan University (TU), one of the oldest and largest university of Nepal, has been launching the semester system in general masters' program from the year 2014 at Central Campus in Kirtipur and from the year 2017 at Kathmandu Valley and planning to launch across the country from the year 2018. The semester system is said to keep students on their toes with their progress being regularly and closely monitored. 
Compared to the annual system, it helps to keep students busy all year round with an even level of burden instead of allowing them to pile up work towards the end of the year. A semester system permits greater freedom and scope for designing and delivering a variety of courses that the students can pick flexibly from in order to enhance the quality of their learning (Singh \& Kuamr, 2016).

It is claimed that implementation of the semester system in TU is to bring about a quantum leap in teaching, research and innovation. Hence the emphasis is given to have more discussion over the following issues:

$\rightarrow \quad$ Can the semester system actually serve its purpose if the structure, policies, infrastructure and resources of the university remain the same?

$\rightarrow \quad$ Have we done anything to change or even try to change the syllabus and teaching methods to suit the new system?

$\rightarrow \quad$ What kind of education system are we trying to establish in this country?

$\rightarrow \quad$ How do the students perceive towards the implementation of semester system in the master of business studies under Tribhuvan University?

\section{Objectives and Hypotheses}

The purpose of the study is to understand and analyze the students' perception towards MBS semester system with regard to (a) academic resources, (b) course organization and planning, (c) physical resources, (d) governance and image.

Semester system has a specified number of working days which helps in better budgeting of available time and resources. This system does not allow any kind of slackness on the part of teachers and students; as they are fully occupied in teaching and learning process. The curriculum under the semester system has prioritized practical learning and an internal assessment on a regular basis. The system is very much learner centered with greater interaction between students and teachers. The study sets following four hypotheses and their relations have been checked and analyzed.

H1: Academic resources affect students' perception.

H2: Course organization and planning affect students' perception.

H3: Physical resources affect students' perception.

H4: Governance and image affect students' perception.

Therefore, the study model is as follows: Image $+\varepsilon$

$\mathrm{Y}=B_{0}+b_{1}$ Acca. Resources $+b_{2}$ Course Org. \& $\mathrm{P}+b_{3}$ Phy. Recourses $+b_{4}$ Gov. \&

\section{Methodology}

The study followed a case study of Nepal Commerce Campus with descriptive survey design. It delimits to students' perception towards MBS semester system at Nepal Commerce Campus. Therefore, 668 students who are studying in Nepal Commerce Campus at MBS semester system (first batch/first semester) were the population of the study. Without prior notice, a self-administered questionnaire was distributed to the all students on Mangsir 04, 2074 - a regular working day. All together 320 students were participated in the survey, 246 questionnaire were properly filled up and returned. Therefore, 246 students (i.e. $36.82 \%$ ) were the sample of the study. 


\section{Data Presentation and Analysis}

The survey questionnaire was set in seven sections with 30 questions of various types. Five questions in section A dealt with demographic information of the respondents; five questions in section $\mathrm{B}$ with academic resources; five questions in section $\mathrm{C}$ with course organization and planning; five questions in section D with physical resources; five questions in section $\mathrm{E}$ with governance and image; two questions in section $\mathrm{F}$ with overall perception and three questions in section $\mathrm{G}$ with concluding remarks. The 22 questions (6 to 27) were used five point Likert scale from 1 to 5, with 1 strongly disagree/very ineffective, 3 can't say and 5 strongly agree/very effective response. Collected data were analyzed with the help of SPSS software (version 23). The sample size of the study was big in comparison with its population size, therefore Likert data were considered for statistical operations like mean and standard deviation. The questionnaire revealed results for seven major sections, each of that is discussed in detailed as under:

\section{Students' Demographic}

The demographic information of the students was designed on the basis of five variables: respondent's education system at bachelor level, bachelor degree, permanent address, province and gender as presented in table 1.

Table 1

Demographic Information the Respondents'

\begin{tabular}{lcc}
\hline & No of students & Percent \\
\hline The student who completed his/her bachelor degree from: & 57 & $23.2 \%$ \\
Semester system & 189 & $76.8 \%$ \\
Annual system & 246 & $100.0 \%$ \\
\hline Total & & \\
\hline The student whose bachelor degree at: & 242 & $98.4 \%$ \\
Management & 2 & $0.8 \%$ \\
Humanities & 1 & $0.4 \%$ \\
Science & 1 & $0.4 \%$ \\
Information Technology & 246 & $100.0 \%$ \\
\hline Total & & \\
\hline Permanent address of the students: & 42 & $17.1 \%$ \\
Inside the Kathmandu Valley & 204 & $82.9 \%$ \\
Outside the Kathmandu Valley & 246 & $100.0 \%$ \\
\hline Total & & \\
The student who came from: & 57 & $23.2 \%$ \\
Province no 1 & 34 & $13.8 \%$ \\
Province no 2 & 90 & $36.6 \%$ \\
Province no 3 & 4 & $1.6 \%$ \\
Province no 4 & 33 & $13.4 \%$ \\
Province no 5 & 6 & $2.4 \%$ \\
Province no 6 & 22 & $8.9 \%$ \\
Province no 7 & 246 & $100.0 \%$ \\
\hline Total & &
\end{tabular}




\begin{tabular}{lcc}
\hline \hline Gender of the students: & & \\
Male & 107 & $43.5 \%$ \\
Female & 139 & $56.5 \%$ \\
\hline Total & 246 & $100.0 \%$ \\
\hline
\end{tabular}

The sample showed that more than $75 \%$ students were new for the semester system. Most of the students (more than $98 \%$ ) joined MBS semester system who completed their bachelor level in management education. Nepal Commerce Campus got $80 \%$ and more students from outside the Kathmandu Valley. Analyzing outside the Valley only, province 1 fed highest number of students and Province 4 and 6 fed least number of students to NCC. The sample included $43.5 \%$ male and $56.5 \%$ female students.

\section{Academic Resources of NCC}

Academic resources of NCC were tested through five questions based on five point Likert scale. The questions were scaled as strongly disagree $(\mathrm{SD})=1$, disagree $(\mathrm{D})=2$, can't say $(\mathrm{C} n \mathrm{~S})=3$, agree $(\mathrm{A})=4$ and strongly agree $(\mathrm{SA})=5$. The value of Cronbach's alpha of the questions, $a=0.747$ which showed the questions were consistent and reliable. Table 2 and table 3 depict the descriptive statistics of the students' perception towards academic resources of NCC.

Table 2

Descriptive Statistics of the Academic Resources of NCC

Total number of respondents, $N=246$

\begin{tabular}{|c|c|c|c|c|c|c|c|c|c|c|}
\hline \multirow{2}{*}{\multicolumn{2}{|c|}{ Statements }} & \multicolumn{5}{|c|}{$\%$ of responses on: } & \multicolumn{4}{|c|}{ Descriptive statistics: } \\
\hline & & SD & $\mathrm{D}$ & $\mathrm{CnS}$ & $\mathrm{A}$ & SA & Mean & S. dev. & t-value & $\mathrm{p}$-value \\
\hline Q6 & $\begin{array}{l}\text { Faculties of NCC have } \\
\text { sufficient experience in } \\
\text { their subject matter } \\
\text { They have updated }\end{array}$ & $2.8 \%$ & $10.2 \%$ & $13.8 \%$ & $62.6 \%$ & $10.6 \%$ & 3.68 & 0.898 & 11.855 & 0.000 \\
\hline Q7 & $\begin{array}{l}\text { knowledge } \\
\text { in their subjects. } \\
\text { They are capable in }\end{array}$ & $1.2 \%$ & $12.2 \%$ & $14.6 \%$ & $59.8 \%$ & $12.2 \%$ & 3.70 & 0.881 & 12.376 & 0.000 \\
\hline Q8 & $\begin{array}{l}\text { handling students' } \\
\text { queries. }\end{array}$ & $1.2 \%$ & $11.4 \%$ & $22.8 \%$ & $56.9 \%$ & $7.7 \%$ & 3.59 & 0.837 & 10.967 & 0.000 \\
\hline Q9 & $\begin{array}{l}\text { They are following } \\
\text { curriculum as } \\
\text { per lecture hours } \\
\text { prescribed by the } \\
\text { syllabus. }\end{array}$ & $1.6 \%$ & $16.3 \%$ & $11.8 \%$ & $57.3 \%$ & $13.0 \%$ & 3.64 & 0.958 & 10.450 & 0.000 \\
\hline Q10 & $\begin{array}{l}\text { They are punctual } \\
\text { (come on time \& leave } \\
\text { on time) }\end{array}$ & $8.5 \%$ & $18.7 \%$ & $13.0 \%$ & $46.4 \%$ & $13.4 \%$ & 3.37 & 1.181 & 4.968 & 0.000 \\
\hline 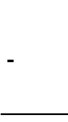 & $\begin{array}{l}\text { Perception towards } \\
\text { overall academic } \\
\text { resources }\end{array}$ & - & - & - & - & - & 3.594 & 0.676 & 13.789 & 0.000 \\
\hline
\end{tabular}


Table 3

Correlation Matric between Academic Resources of NCC

Total number of respondents, $N=246$

\begin{tabular}{|c|c|c|c|c|c|c|}
\hline \multicolumn{2}{|c|}{ Statements } & $\mathrm{X} 6$ & $\mathrm{X} 7$ & $\mathrm{X} 8$ & $\mathrm{X} 9$ & $\mathrm{X} 10$ \\
\hline & Faculties of NCC have sufficient & & $0.639 * *$ & $0.495^{* *}$ & $0.334^{* *}$ & $0.279^{* *}$ \\
\hline 160 & experience in their subject matter - X6 & & $(0.000)$ & $(0.000)$ & $(0.000)$ & $(0.000)$ \\
\hline Q7 & $\begin{array}{l}\text { They have updated knowledge } \\
\text { in their subjects - X7 }\end{array}$ & & & $\begin{array}{l}0.503^{* *} \\
(0.000)\end{array}$ & $\begin{array}{l}0.362^{* * *} \\
(0.000)\end{array}$ & $\begin{array}{l}0.259^{* *} \\
(0.000)\end{array}$ \\
\hline & They are capable in handling & & & & $0.331^{* *}$ & $0.335^{* * *}$ \\
\hline 188 & $\begin{array}{l}\text { students' queries - X8 } \\
\text { They are following curriculum as per lecture }\end{array}$ & & & & $(0.000)$ & $\begin{array}{l}(0.000) \\
0.362^{* *}\end{array}$ \\
\hline Q10 & $\begin{array}{l}\text { hours prescribed by the syllabus - X9 } \\
\text { They are punctual (come on time \& } \\
\text { leave on time) - X10 }\end{array}$ & & & & & $(0.000)$ \\
\hline
\end{tabular}

All the statements relating to academic resources were significant and had good mean value (greater than 3). Items correlations were positive and significant at the 0.01 level of significance. Based on these statistics, students were satisfied on the overall academic resources of NCC. However, they made a request to maintain punctuality of the faculty members.

\section{Course Organization and Planning by the Faculties}

Course organization and planning by the faculties were tested through five questions based on five point Likert scale. The questions were scaled as very ineffective $(\mathrm{VI})=1$, ineffective $(\mathrm{I})=2$, can't say $(\mathrm{C} n \mathrm{~S})=3$, effective $(\mathrm{E})=4$ and very effective $(\mathrm{VE})=5$. The value of Cronbach's alpha of the questions, $a=0.793$ which showed the questions were consistent and reliable. Table 4 and table 5 depict the students' perception towards course organization and planning.

Table 4

Descriptive Statistics of the Course Organization and Planning of NCC

Total number of respondents, $N=246$

\begin{tabular}{|c|c|c|c|c|c|c|c|c|c|}
\hline \multirow{2}{*}{ Statements } & \multicolumn{5}{|c|}{ \% of responses on: } & \multicolumn{4}{|c|}{ Descriptive statistics: } \\
\hline & VI & I & $\mathrm{C} n \mathrm{~S}$ & $\mathrm{E}$ & $\mathrm{VE}$ & Mean & S.dev. & t-value & p-value \\
\hline $\begin{array}{l}\text { The faculty's explanation } \\
\text { of course requirements }\end{array}$ & $1.6 \%$ & $14.6 \%$ & $12.6 \%$ & $66.7 \%$ & $4.5 \%$ & 3.58 & 0.852 & 10.621 & 0.000 \\
\hline $\begin{array}{l}\text { The faculty's preparation } \\
\text { for each class period }\end{array}$ & $2.4 \%$ & $16.7 \%$ & $19.5 \%$ & $56.5 \%$ & $4.9 \%$ & 3.45 & 0.910 & 7.708 & 0.000 \\
\hline $\begin{array}{l}\text { The faculty's command } \\
\text { on the subject matter }\end{array}$ & $1.2 \%$ & $12.6 \%$ & $21.1 \%$ & $57.3 \%$ & $7.8 \%$ & 3.58 & 0.852 & 10.621 & 0.000 \\
\hline $\begin{array}{l}\text { The faculty's use of class } \\
\text { time }\end{array}$ & $1.6 \%$ & $13.8 \%$ & $16.3 \%$ & $57.7 \%$ & $10.6 \%$ & 3.62 & 0.908 & 10.671 & 0.000 \\
\hline $\begin{array}{l}\text { The faculty's way } \\
\text { of summarizing/ } \\
\text { emphasizing important } \\
\text { points in class }\end{array}$ & $4.9 \%$ & $16.3 \%$ & $17.1 \%$ & $53.2 \%$ & $8.6 \%$ & 3.44 & 1.020 & 6.816 & 0.000 \\
\hline
\end{tabular}


Pravaha Journal-2018

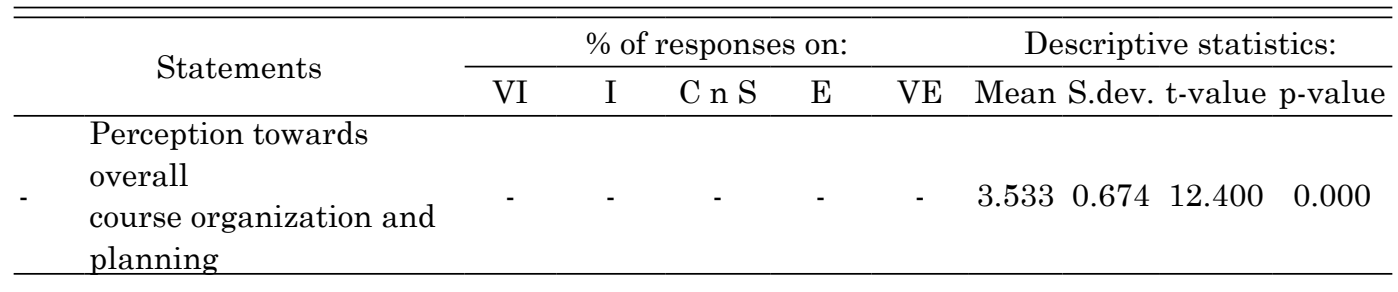

Table 5

Correlation Matric between Academic Resources of NCC

Total number of respondents, $N=246$

\begin{tabular}{|c|c|c|c|c|c|}
\hline Statements & $\mathrm{X} 11$ & $\mathrm{X} 12$ & $\mathrm{X} 13$ & $\mathrm{X} 14$ & $\mathrm{X} 15$ \\
\hline The faculty's explanation & & $0.508^{* * *}$ & $0.405^{* *}$ & $0.339 * *$ & $0.404^{* *}$ \\
\hline Q11 of course requirements $-\mathrm{X} 11$ & & $(0.000)$ & $(0.000)$ & $(0.000)$ & $(0.000)$ \\
\hline 11 The faculty's preparation & & & $0.560 * *$ & $0.395^{* *}$ & $0.349 * *$ \\
\hline Q12 for each class period $-\mathrm{X} 12$ & & & $(0.000)$ & $(0.000)$ & $(0.000)$ \\
\hline $\begin{array}{l}\text { The faculty's command } \\
\text { on the subject matter - X13 }\end{array}$ & & & & $\begin{array}{c}0.550^{* * *} \\
(0.000)\end{array}$ & $\begin{array}{c}0.508^{* *} \\
(0.000)\end{array}$ \\
\hline Q14 The faculty's use of class time - X14 & & & & & $\begin{array}{r}0.373^{* *} \\
(0.000)\end{array}$ \\
\hline $\begin{array}{l}\text { Q15e faculty's way of summarizing/ } \\
\text { emphasizing important points in class - X15 }\end{array}$ & & & & & \\
\hline
\end{tabular}

All the statements relating to course organization and planning were significant and had good mean value (greater than 3). Items correlations were positive and significant at the 0.01 level of significance. Students had good perception towards course organization and planning. They had a request on the summarizing/emphasizing important terms and points in the class.

\section{Physical Resources of the NCC}

Physical resources of NCC were tested through five questions based on five point Likert scale. The questions were scaled as strongly disagree $(\mathrm{SD})=1$, disagree $(\mathrm{D})=2$, can't say $(\mathrm{C} n \mathrm{~S})=3$, agree $(\mathrm{A})=4$ and strongly agree $(\mathrm{SA})=5$. The value of Cronbach's alpha of the questions, $\alpha=0.602$ which showed respondents had different perception towards physical resources and the questions had acceptable level of consistency and reliability. Table 5 and table 6 depict the students' perception towards physical resources of $\mathrm{NCC}$.

Table 5

Descriptive Statistics of the Physical Resources of NCC

Total number of respondents, $N=246$

\begin{tabular}{llllllllll}
\hline \multirow{2}{*}{ Statements } & \multicolumn{4}{c}{$\%$ of responses on: } & \multicolumn{4}{c}{ Descriptive statistics: } \\
\cline { 2 - 9 } & SD & D & C n S & A & SA & Mean & S.dev. t-value p-value \\
\hline $\begin{array}{c}\text { The class rooms are } \\
\begin{array}{c}\text { Q16 good in size with } \\
\text { comfortable furniture }\end{array}\end{array}$ & $13.0 \%$ & $19.5 \%$ & $7.3 \%$ & $51.6 \%$ & $8.6 \%$ & 3.23 & 1.235 & 2.942 & 0.004 \\
\hline
\end{tabular}




\begin{tabular}{|c|c|c|c|c|c|c|c|c|c|}
\hline \multirow{2}{*}{ Statements } & \multicolumn{5}{|c|}{ \% of responses on: } & \multicolumn{4}{|c|}{ Descriptive statistics: } \\
\hline & SD & $\mathrm{D}$ & $\mathrm{CnS}$ & A & $\mathrm{SA}$ & Mean & S.dev. & t-value & $\mathrm{p}$-value \\
\hline The class rooms & & & & & & & & & \\
\hline $\begin{array}{l}\text { Q17 have well working } \\
\text { computers and } \\
\text { projectors }\end{array}$ & $6.5 \%$ & $22.4 \%$ & $25.6 \%$ & $40.6 \%$ & $4.9 \%$ & 3.15 & 1.033 & 2.284 & 0.023 \\
\hline $\begin{array}{l}\text { Q18 } \\
\text { library facility } \\
\text { Canteen is neat } \mathrm{n}\end{array}$ & $6.9 \%$ & $25.6 \%$ & $11.8 \%$ & $47.2 \%$ & $8.5 \%$ & 3.25 & 1.135 & 3.425 & 0.001 \\
\hline $\begin{array}{l}\text { Q19 clean and provides } \\
\text { fresh/hygienic food }\end{array}$ & $17.5 \%$ & $19.5 \%$ & $39.8 \%$ & $21.6 \%$ & $1.6 \%$ & 2.70 & 1.045 & -4.456 & 0.000 \\
\hline Q20 $\begin{array}{l}\text { Toilets are sufficient, } \\
\text { clean and satisfactory }\end{array}$ & $54.9 \%$ & $30.1 \%$ & $6.9 \%$ & $7.7 \%$ & $0.4 \%$ & 1.69 & 0.932 & -22.092 & 0.000 \\
\hline $\begin{array}{l}\text { Perception towards } \\
\text { overall physical } \\
\text { resources }\end{array}$ & - & - & - & - & - & 2.804 & 1.235 & -4.577 & 0.000 \\
\hline
\end{tabular}

Table 6

Correlation Matric between Physical Resources of NCC

Total number of respondents, $N=246$

\begin{tabular}{llcccc}
\hline Statements & X16 & X17 & X18 & X19 & X20 \\
\hline \multirow{2}{*}{ Q16 16 The class rooms are good in size with } & $0.388^{* *}$ & $0.288^{* *}$ & $0.294^{* *}$ & $0.237^{* *}$ \\
comfortable furniture - X16 & $(0.000)$ & $(0.000)$ & $(0.000)$ & $(0.000)$ \\
The class rooms have well working & & & 0.097 & $0.250^{* *}$ & 0.087 \\
Q17 & & $(0.130)$ & $(0.000)$ & $(0.173)$ \\
computers and projectors - X17 & & & $0.176^{* *}$ & $0.182^{* *}$ \\
NCC has upto date library facility - & & & $(0.006)$ & $(0.004)$ \\
Q18 & & & & $0.302^{* *}$ \\
X18 & & & & $(0.000)$ \\
Q19 & & & & \\
Canteen is neat n clean and provides & & & & \\
fresh/hygienic food - X19 & & & & \\
Q20ilets are sufficient, clean and & & & & \\
satisfactory - X20
\end{tabular}

The statements relating to class room size and furniture, class room computers and projectors, and library facility had good mean value (greater than 3) whereas the statements relating to canteen and toilets had poor mean value (less than 3 ). The table 6 showed that all items correlations were positive but there were weak positive insignificant relationship between class room computers and projectors with library and toilets facilities. Students were satisfied with classroom size, working computers and projectors as well as library facility. But they were strongly dissatisfied with toilet facilities and canteen. Around $40 \%$ students were dissatisfied with canteen's food and services. Another $40 \%$ students were not using canteen facilities whereas around 20 $\%$ students were satisfied with canteen's services. $85 \%$ students were dissatisfied with NCC's toilets. They had strong request to add toilets and maintain cleanliness.

\section{Governance and Image of the NCC}

Governance and image of the NCC were also tested through five questions based on five point Likert scale. The questions were scaled as strongly disagree (SD) $=1$, 
disagree $(\mathrm{D})=2$, can't say $(\mathrm{C} n \mathrm{~S})=3$, agree $(\mathrm{A})=4$ and strongly agree $(\mathrm{SA})=5$. The value of Cronbach's alpha of the questions, $\alpha=0.781$ which showed the questions were consistent and reliable. Table 7 and table 8 depict the students' perception towards governance and image of NCC.

Table 7

Descriptive Statistics of Governance and Image of NCC

Total number of respondents, $N=246$

\begin{tabular}{|c|c|c|c|c|c|c|c|c|c|c|}
\hline \multirow{2}{*}{\multicolumn{2}{|c|}{ Statements }} & \multicolumn{5}{|c|}{$\%$ of responses on: } & \multicolumn{4}{|c|}{ Descriptive statistics: } \\
\hline & & $\mathrm{SD}$ & $\mathrm{D}$ & $\mathrm{CnS}$ & $\mathrm{A}$ & $\mathrm{SA}$ & Mean & S.dev. & t-value & p-value \\
\hline Q21 & $\begin{array}{l}\text { Administrative staff of } \\
\text { NCC are cooperative } \\
\text { and responsive } \\
\text { Role of the campus }\end{array}$ & $6.1 \%$ & $19.1 \%$ & $17.5 \%$ & $53.7 \%$ & $3.6 \%$ & 3.30 & 1.017 & 4.577 & 0.000 \\
\hline Q22 & $\begin{array}{l}\text { chief and program } \\
\text { coordinators are } \\
\text { supportive }\end{array}$ & $4.1 \%$ & $16.7 \%$ & $32.1 \%$ & $43.9 \%$ & $3.2 \%$ & 3.26 & 0.914 & 4.393 & 0.000 \\
\hline Q23 & $\begin{array}{l}\text { Students' problems are } \\
\text { promptly resolved } \\
\text { NCC is going to create }\end{array}$ & $9.4 \%$ & $32.1 \%$ & $32.9 \%$ & $24.0 \%$ & $1.6 \%$ & 2.76 & 0.974 & -3.797 & 0.000 \\
\hline Q24 & $\begin{array}{l}\text { brand image of MBS } \\
\text { Semester System }\end{array}$ & $2.4 \%$ & $6.9 \%$ & $35.8 \%$ & $46.3 \%$ & $8.6 \%$ & 3.52 & 0.841 & 9.624 & 0.000 \\
\hline Q25 & $\begin{array}{l}\text { I am glad - that I came } \\
\text { to this campus }\end{array}$ & $0.8 \%$ & $7.3 \%$ & $17.1 \%$ & $61.4 \%$ & $13.4 \%$ & 3.79 & 0.794 & 15.660 & 0.000 \\
\hline - & $\begin{array}{l}\text { Perception towaras } \\
\text { overall governance and } \\
\text { image }\end{array}$ & - & - & - & - & - & 3.325 & 0.666 & 7.663 & 0.000 \\
\hline
\end{tabular}

Table 8

Correlation Matric between Governance and Image of NCC

Total number of respondents, $N=246$

\begin{tabular}{llcccc}
\hline \multicolumn{1}{c}{ Statements } & X21 & X22 & X23 & X24 & X25 \\
\hline Q21 & Administrative staff of NCC are cooperative & $0.414^{* *}$ & $0.442^{* *}$ & $0.288^{* *}$ & $0.395^{* *}$ \\
and responsive - X21 & $(0.000)$ & $(0.000)$ & $(0.000)$ & $(0.000)$ \\
R2 & & & $0.526^{* *}$ & $0.310^{* *}$ & $0.428^{* *}$ \\
Role of the campus chief and program & & $(0.000)$ & $(0.000)$ & $(0.000)$ \\
coordinators are supportive - X22 & & & $0.473^{* *}$ & $0.412^{* *}$ \\
Students' problems are promptly resolved - & & & $(0.000)$ & $(0.000)$ \\
Q23 & & & & $0.521^{* * *}$ \\
X23 & & & & $(0.000)$ \\
Q24 & & & & \\
SCC is going to create brand image of MBS & & & & \\
Q25 I am glad - that I came to this campus - X25 & & &
\end{tabular}

All the statements relating to governance and image had satisfactory mean value (greater than 3) except solving students' problems promptly. The table 8 showed that all items correlations were positive and significant. Although students' problems were not promptly resolved, they had good perception towards college governance and 
image.

\section{Overall perception of the students}

Overall perception of the students was tested through two questions based on five point Likert scale. The questions were scaled as strongly disagree (SD) $=1$, disagree $(\mathrm{D})=2$, can't say $(\mathrm{C} n \mathrm{~S})=3$, agree $(\mathrm{A})=4$ and strongly agree $(\mathrm{SA})=5$. Table 9 and table 10 present overall perception of the students' towards MBS semester system.

Table 9

Descriptive Statistics of Overall Perception of NCC

Total number of respondents, $N=246$

\begin{tabular}{|c|c|c|c|c|c|c|c|c|c|}
\hline \multirow{2}{*}{ Statements } & \multicolumn{5}{|c|}{$\%$ of responses on: } & \multicolumn{4}{|c|}{ Descriptive statistics: } \\
\hline & SD & $\mathrm{D}$ & $\mathrm{CnS}$ & $\mathrm{A}$ & $\mathrm{SA}$ & Mean & S.dev. & t-value & $p$-value \\
\hline $\begin{array}{l}\text { MBS semester curriculum } \\
\text { provides standard }\end{array}$ & & & & & & & & & \\
\hline $\begin{array}{l}\text { Q26 knowledge required for } \\
\text { masters level management } \\
\text { students. }\end{array}$ & $0.4 \%$ & $8.1 \%$ & $12.2 \%$ & $68.3 \%$ & $11.0 \%$ & 3.81 & .749 & 17.028 & 0.000 \\
\hline $\begin{array}{l}\text { Semester system is an } \\
\text { innovative approach to } \\
\text { teaching-learning process, } \\
\text { Q27 a new educational culture, } \\
\text { which allows greater } \\
\text { interaction between } \\
\text { teachers and students }\end{array}$ & $1.6 \%$ & $7.3 \%$ & $9.3 \%$ & $58.2 \%$ & $23.6 \%$ & 3.95 & 0.877 & 16.945 & 0.000 \\
\hline $\begin{array}{l}\text { Perception towards } \\
\text { overall perception }\end{array}$ & - & - & - & - & - & 3.880 & 0.678 & 20.396 & 0.000 \\
\hline
\end{tabular}

Table 10

Correlation Matric between Overall Perceptions towards MBS Semester System

Total number of respondents, $N=246$

\begin{tabular}{|c|c|c|c|c|}
\hline Statements & $\mathrm{X} 26 \mathrm{X} 27$ & $\mathrm{X} 28$ & X29 & X30 \\
\hline Overall perception towards NCC's academic resources & $0.653^{* *}$ & $0.442^{* * *}$ & $0.481^{* *}$ & $0.255^{* *}$ \\
\hline$-\mathrm{X} 26$ & $(0.000)$ & $(0.000)$ & $(0.000)$ & $(0.000)$ \\
\hline Overall perception towards NCC facilities' course & & $0.483^{* *}$ & $0.524 * *$ & $0.253^{* *}$ \\
\hline $\begin{array}{l}\text { organization and planning }- \text { X27 } \\
\text { Overall perception towards NCC's physical resources }\end{array}$ & & $(0.000)$ & $\begin{array}{l}(0.000) \\
0.565^{* *}\end{array}$ & $\begin{array}{l}(0.000) \\
0.298^{* * *}\end{array}$ \\
\hline$-\mathrm{X} 28$ & & & $(0.000)$ & $(0.000)$ \\
\hline Overall perception towards NCC's governance and & & & & $0.400 * *$ \\
\hline $\begin{array}{l}\text { image - X29 } \\
\text { Overall perception towards MBS semester system - }\end{array}$ & & & & $(0.000)$ \\
\hline
\end{tabular}

More than $80 \%$ students had good perception on MBS semester curriculum and teaching-learning process. 


\section{Testing Hypotheses}

Table 11 showed model summary after running multiple linear regression between overall students' perception (dependent variable) with academic resources, course organization and planning, physical resources, and governance and image (as independent variables). The model summary displayed that the independent variables explained only $17.2 \%$ on overall students' perception towards MBS semester system.

Table 11

Model Summary of Students' Perception b

\begin{tabular}{ccccc}
\hline Model & $\mathrm{R}$ & $\mathrm{R}$ Square & Adjusted R Square & Std. Error of the Estimate \\
\hline 1 & $0.414 \mathrm{a}$ & 0.172 & 0.158 & 0.62103 \\
\hline
\end{tabular}

a. Predictors: (Constant), Academic resources, Course organization and planning, physical resources, governance and image

b. Dependent variable: Overall students' perception

Table 12 explained that the overall model was statistically significant that means all the independent variables - academic resources, course organization and planning, physical resources, governance and image were connected to the overall students' perception - dependent variable.

Table 12

ANOVA a Result of Students' Perception

\begin{tabular}{ccccccc}
\hline & Model & Sum of Squares & df & Mean Square & F & Sig. \\
\hline & Regression & 19.265 & 4 & 4.816 & 12.488 & $0.000 \mathrm{~b}$ \\
\multirow{4}{*}{1} & Residual & 92.947 & 241 & .386 & & \\
& Total & 112.212 & 245 & & & \\
\hline
\end{tabular}

a. Dependent variable: Overall students' perception

b. Predictors: (Constant), Academic resources, Course organization and planning, physical resources, governance and image

Table 13

Regression Co-efficient of Overall Students' Perception

\begin{tabular}{lcccccc}
\hline \multirow{2}{*}{ Model } & \multicolumn{2}{c}{$\begin{array}{c}\text { Unstandardized } \\
\text { Coefficients a }\end{array}$} & $\begin{array}{c}\text { Standardized } \\
\text { coefficients }\end{array}$ & t-value & Sig. & Remarks \\
\cline { 2 - 5 } & $\mathrm{B}$ & Std. Error & Beta & & & \\
\hline (Constant) & 2.302 & 0.252 & & 9.145 & 0.000 & - \\
Academic resources & 0.075 & 0.079 & 0.075 & 0.945 & 0.346 & Rejected \\
$\begin{array}{l}\text { Course organization \& } \\
\text { planning }\end{array}$ & -0.008 & 0.085 & -0.008 & -0.096 & 0.923 & Rejected \\
Physical resources & 0.099 & 0.074 & 0.099 & 1.337 & 0.182 & Rejected \\
Governance and image & 0.318 & 0.079 & 0.313 & 4.032 & 0.000 & Accepted \\
\hline
\end{tabular}

a. Dependent variable: Overall students' perception

Regression equation: $\mathrm{Y}=\mathrm{B} 0+\mathrm{B} 1 \mathrm{X} 1+\mathrm{B} 2 \mathrm{X} 2+\mathrm{B} 3 \mathrm{X} 3+\mathrm{B} 4 \mathrm{X} 4+\varepsilon$ 
Regression equation for the study, $\mathrm{Y}=\mathrm{B} 0+$ B1 Acca. Resources +82 Course Org. \& $\mathrm{P}+83$ Phy. Recourses +84 Gov. $\&$ Image $+\varepsilon$

$\mathrm{Y}=2.302+0.075$ A. Resources -0.008 Course Org. \& P + 0.099 P. Recourses + 0.318 Gov. \& Image $+\varepsilon$

Interestingly, table 13 showed that students' perception depend upon college governance and image rather than academic resources, course organization and planning, and physical resources. The masters' level students showed negative perception with course organization and planning. They didn't much focus on academic and physical resources.

\section{Students' suggestions and feedback}

In the last section of the questionnaire, there were three open ended questions that sought suggestions and feedback from the respondents for the betterment of the program and the campus. In response to the first question 'if you believe that your classroom and other physical facilities of the campus need improvement', they said:

Toilets are insufficient and so dirty. Maintain cleanliness, build some new toilets and arrange regular water facility;

$\rightarrow \quad$ Drinking water supply is not enough;

$\rightarrow \quad$ Furniture are not comfortable, replace with good one;

$\rightarrow \quad$ Classrooms should open on time, clean regularly and provide dustbin for every classroom;

$\rightarrow \quad$ Classroom CPU \& projector are not working properly and should install antivirus;

$\rightarrow \quad$ Sunlight directly affects eyes, so cover with curtains (section A and B);

$\rightarrow \quad$ Get distracted by noise from outside;

$\rightarrow \quad$ Provide break time for tea and food;

$\rightarrow \quad$ Need some extra activities like - field visit, workshops; seminars; games, tours etc.;

$\rightarrow \quad$ Maintain and improve garden;

$\rightarrow \quad$ Faculties usually comes with poor ink markers without duster;

$\rightarrow \quad$ Use thumb machine for students' attendance;

$\rightarrow \quad$ Evening class rooms are so dirty; need to clean the classrooms promptly;

$\rightarrow \quad$ Library should open on appropriate time, update regularly and start e-library etc.

In response to the second question if you believe that your faculties need improvement', they said:

$\rightarrow \quad$ Faculties are focusing on theories and lecture method. We want discussions, cases, presentations and real life examples;

$\rightarrow \quad$ Most of the faculties are not using projectors, enter into the class lately and leave early - especially on theory subjects;

$\rightarrow \quad$ Some faculties should focus on contents rather than unnecessary imaginary story and need to improve teaching methodology; 
$\rightarrow \quad$ Some faculties need to improve their knowledge to teach on master's level semester class;

$\rightarrow \quad$ Managerial communication should be taught in English rather than Nepali and provide relevant reading materials;

$\rightarrow \quad$ In some sections, we are not understanding organization behavior and marketing lectures; whereas in others, we have a problem on economics, managerial communication and statistics. Hence, we request the college management to properly diagnose and address the issues;

$\rightarrow \quad$ Some faculties are using their own books only, it would be better to use standard text books prescribed by the syllabus;

$\rightarrow \quad$ Prior notice should be given by faculties if they are going to be absent;

$\rightarrow \quad$ It would better to have dress code for teachers etc.

In response to the third question 'if you have any suggestion/(s) for the betterment of the campus' they said:

$\rightarrow \quad$ Administrative staff should use polite language and be cooperative;

$\rightarrow \quad$ There is poor coordination between management and students;

$\rightarrow \quad$ Notices for the students should be communicated on time;

$\rightarrow \quad$ Avoid unnecessary holidays/leave;

$\rightarrow \quad$ No of students should be 30 in a class;

$\rightarrow \quad$ Reduce fee;

$\rightarrow \quad$ Students should be allowed to write either in English or in Nepali in the exam;

$\rightarrow \quad$ Arrange some guest lectures;

$\rightarrow \quad$ Campus chief/program coordinator should interact with student frequently;

$\rightarrow \quad$ College should arrange personality/leadership development program as well as seminars/ workshops etc.

\section{Discussion and Conclusions}

By comparing construct-wise perception with categorical variables, table 14 depicts students' perception towards overall academic resources, course organization and planning, physical resources, and governance and image of NCC.

Table 14

Comparison of Construct-wise Perception by Categorical Variables

\begin{tabular}{|c|c|c|c|c|c|}
\hline & $\begin{array}{c}\text { No } \\
\text { of } \\
\text { Res. }\end{array}$ & $\begin{array}{l}\text { Academic } \\
\text { resources }\end{array}$ & $\begin{array}{c}\text { Course } \\
\text { organization } \\
\text { and planning }\end{array}$ & $\begin{array}{l}\text { Physical } \\
\text { resources }\end{array}$ & $\begin{array}{l}\text { Governance } \\
\text { and image }\end{array}$ \\
\hline Bachelor degree in: & & $\begin{array}{ll}\text { Mean } & \text { St. } \\
\text { dev. }\end{array}$ & Mean St. dev. & $\begin{array}{cc}\text { Mean } & \begin{array}{c}\text { St. } \\
\text { dev. }\end{array}\end{array}$ & $\begin{array}{ll}\text { Mean } & \text { St. } \\
\text { dev. }\end{array}$ \\
\hline Semester system & 57 & 3.6810 .623 & $3.446 \quad 0.712$ & $2.568 \quad 0.729$ & 3.2420 .678 \\
\hline Annual system & 189 & 3.5680 .691 & $3.559 \quad 0.661$ & 2.8750 .638 & $3.350 \quad 0.662$ \\
\hline Total & 246 & 3.5940 .676 & $3.533 \quad 0.674$ & $2.804 \quad 0.671$ & $3.325 \quad 0.666$ \\
\hline \multicolumn{6}{|l|}{ Permanent address: } \\
\hline Inside the Kathmandu Valley & 42 & $3.300 \quad 0.849$ & $3.252 \quad 0.826$ & 2.7290 .702 & $3.186 \quad 0.641$ \\
\hline
\end{tabular}




\begin{tabular}{lccccccccc}
\hline \hline & $\begin{array}{c}\text { No } \\
\text { of } \\
\text { Res. }\end{array}$ & $\begin{array}{c}\text { Academic } \\
\text { resources }\end{array}$ & \multicolumn{2}{c}{$\begin{array}{c}\text { Course } \\
\text { organization } \\
\text { and planning }\end{array}$} & $\begin{array}{c}\text { Physical } \\
\text { resources }\end{array}$ & $\begin{array}{c}\text { Governance } \\
\text { and image }\end{array}$ \\
\hline Outside the Kathmandu Valley & 204 & 3.655 & 0.620 & 3.590 & 0.623 & 2.820 & 0.657 & 3.354 & 0.669 \\
\hline Total & 246 & 3.594 & 0.676 & 3.533 & 0.674 & 2.804 & 0.671 & 3.325 & 0.666 \\
\hline $\begin{array}{l}\text { Gender } \\
\text { Male }\end{array}$ & 107 & 3.488 & 0.714 & 3.408 & 0.704 & 2.701 & 0.746 & 3.340 & 0.694 \\
Female & 139 & 3.676 & 0.636 & 3.629 & 0.635 & 2.884 & 0.599 & 3.391 & 0.637 \\
\hline Total & 246 & 3.594 & 0.676 & 3.533 & 0.674 & 2.804 & 0.671 & 3.325 & 0.666 \\
\hline
\end{tabular}

The study found that the students who were from semester system at bachelor level have good perception than the students who were from annual system on the overall academic resources of NCC. On the other hand, the students from the annual system perceived better on course organization and planning, physical resources, and governance and image than the students from the semester system. In the permanent address of the respondents category, the students came from outside the Kathmandu Valley were more satisfied at MBS semester system than the students from the Kathmandu Valley. Similarly, female students' perception in all categories were good than the male students.

The forgoing results and discussion portrayed a detailed picture of how students perceive towards the different aspects of MBS semester system at Nepal Commerce Campus. The result revealed that most of the students perceived semester system is an innovative approached to teaching-learning process, a new educational culture, which allows greater interaction between teachers and students (mean value $=3.95$ and standard deviation $=0.877$ ). They were satisfied with NCC's academic resources but were strongly dissatisfied with canteen and toilets facilities. Among the factors analyzed, governance and image had great influential factor on overall perception.

\section{Limitations and Implications}

The study included those students who were studying MBS semester system since the last five out of 48 month's course cycle. Therefore, the study didn't cover the aspects of semester like syllabus design and coverage, secrecy and confidentiality in examination; transparency in evaluation and grade; timely declaration of semester results etc. Similarly, the study covered a case of Nepal Commerce Campus. Hence, the most obvious limitation of the study was the generalizeability.

The semester system for higher education program, especially at Tribhuvan University, is at transitional phase. It is expected that the old annual education system is going to be replaced by the semester system with a competent performance. The study enhances the understanding of stakeholders about the issues of semester system at master's level.

\section{References}

A Dictionary of Education. London: Harper \& Row

Aslam, H.D, Younis, A., Sheik, A.M, Maher, M. \& Abbasi, Z.A. (2012). Analyzing factors affecting students' satisfaction regarding semester system in universities of Pakistan. Journal of 
American Science, 8 (10), 163-170.

Bazdar, A. (2013). Assessment of student's learning achievement under semester system in Pakistan. Retrieved from http://www.textroad.com, on 22.11.2016

Bhattacharyya, S. (2011). The Semesterisation' Impasse at Delhi University. Economic and Political Weekly, Vol. XLVI (19), May 7, 2011, 22-25.

Brophy, B. (2014). Semestering and teaching-learning situation. Retrieved from http//:www.jstor. org/stable/1494499, on 22.11.2016.

Das, R. (2015). A study on students' perception about the implementation of semester system in the undergraduate colleges under Dibrugarh University. Dimorian Review, 3(6), Retrieved from http://www.dimorianreview.com/2015/11/a-study-on-students-perception-about. html\#axzz4Qk3AgviE

Jadoon, J.I., Jabeen, N., \& Zeba, F. (2012). Towards effective implementation of semester system in Pakistan: lessons from Punjab University, 2nd International Conference on Assessing Quality in Higher Education, 1st - 3rd December 2008, Lahore - Pakistan, 364-373. [Online] Available: http://www.icaqhe2010.org/(November 10, 2017)

Khattak, Z. I., Ali, M., Khan, A \& Khan, S. (2011). A study of English teacher and student's perception about the differences between annual and semester system of education at postgraduate level in Mardan. Procedia Social and Behavioral Sciences, 15, 1693-1643. Retrieved from http//:www.sciencedirect.com

Mallik, P.S. (2013). A study on implementation of semester system of examination in undergraduate course of Calcutta University. Indian Journal of Applied Research, 3 (11), 122-124.

Mazumdar, M. (2010). Introduction of semester system in Indian Colleges, Retrieved from http:// www.grin.com/en/e-book/177187/introduction-of-semester-system-in-indian-colleges

Pathak, T \& Rahman, A. (2013). Perception of student and teachers towards semester system, Retrieved from http://www.iiste.org, on 24.11.2016.

Pokharel, T. (n.d). Management education in Nepal: status, spatial distribution and gender diversity. Retrieved from http://dms.nasc.org.np/sites/default/files/documents /Mangement\%20Education\%20in\%20Nepal.pdf

Sing, V.K. \& Kumar, P. (2016). Challenges in implementation of semester system in globalized world. International Journal of Applied Research. 2 (3), 89-91.

Tribus, M. (1994). Total Quality Management in Education: Developing Quality System in Education. Geoffery D. Dohety (Ed.). London \& New York, NY: Routledge.

Yousaf, H. \& Hashim, M. (2012). A case study of annual and semester system of examination on sciences. International Journal of Academic Research in Business and Social. 2, 200-209. 